EXTENDED REPORT

\title{
Interleukin (IL) 18 stimulates osteoclast formation through synovial T cells in rheumatoid arthritis: comparison with IL1 $\beta$ and tumour necrosis factor $\alpha$
}

\author{
S-M Dai, K Nishioka, K Yudoh
}

Ann Rheum Dis 2004;63:1379-1386. doi: 10.1136/ard.2003.018481

See end of article for authors' affiliations

Correspondence to:

Dr K Yudoh, Department of Bioregulation, Institute of Medical Science, St Marianna University School of Medicine, 2-161 Sugao, Miyamae-ku, Kawasaki, Kanagawa 216-8512, Japan; yudo@ marianna-u.ac.jp

Accepted

29 December 2003

\begin{abstract}
Objective: To determine whether IL18 has any indirect effects on osteoclastogenesis mediated by T cells in RA synovium, and compare its effects with those of ILI $\beta$ and TNF $\alpha$.

Methods: Resting T cells were isolated from peripheral blood of healthy donors, and stimulated with $2 \mu \mathrm{g} /$ $\mathrm{ml}$ phytohaemagglutinin (PHA) and $0.5 \mathrm{ng} / \mathrm{ml}$ IL2 for 24 hours. Synovial T cells were isolated from RA synovial tissue. The levels of soluble receptor activator of the NF- $K B$ ligand (RANKL), osteoprotegerin (OPG), IFN $\gamma$, M-CSF, and GM-CSF were determined by ELISA. Membrane bound RANKL expression was analysed by flow cytometry. Commercially available human osteoclast precursors were cocultured with T cells to induce osteoclast formation, which was determined with tartrate resistant acid phosphatase staining and pit formation assay.

Results: In PHA prestimulated T cells or RA synovial T cells, IL18, IL1 $\beta$, or TNF $\alpha$ increased soluble RANKL production and membrane bound RANKL expression in a dose dependent manner. IL18, IL1 $\beta$, and TNF $\alpha$ did not induce M-CSF, GM-CSF, IFN $\gamma$, or OPG production in PHA prestimulated T cells or RA synovial T cells. IL1 8 increased the number of osteoclasts and bone resorption area on dentine slices in the coculture of human osteoclast precursors with PHA prestimulated T cells or RA synovial T cells; its ability was equivalent to that of IL1 $\beta$, but less potent than that of TNF $\alpha$. In the coculture system, OPG completely blocked osteoclast induction by IL18 or IL1 $\beta$, and greatly inhibited induction by TNF $\alpha$.

Conclusion: IL18, ILI $\beta$, or TNF $\alpha$ can indirectly stimulate osteoclast formation through up regulation of RANKL production from T cells in RA synovitis; IL18 is as effective as IL1 $\beta$, but less potent than TNF $\alpha$.
\end{abstract}

$\mathrm{R}$ heumatoid arthritis (RA) is the most severe chronic joint disease owing to persistent inflammation and destruction of cartilage and bone. The latter is a characteristic feature of RA usually not seen in other forms of inflammatory arthritis and is a major cause of progressive disability and crippling of patients with RA. The mechanisms leading to joint destruction still have not been fully elucidated.

Recently, the role of osteoclasts in bone destruction of RA has attracted growing interest. Osteoclast progenitors differentiate into mature osteoclasts in the presence of receptor activator of NF- $\kappa \mathrm{B}$ ligand (RANKL) on stromal or osteoblastic cells and monocyte/macrophage-colony stimulating factor (M-CSF). The soluble RANKL induces the same differentiation in vitro without stromal cells. RANKL is an essential factor for osteoclast differentiation, ${ }^{1}$ and is also known as $\mathrm{ODF}^{2}$ OPGL, ${ }^{3}$ and TRANCE. ${ }^{4}$ Osteoprotegerin (OPG) is a decoy receptor that binds to $\mathrm{RANKL}^{5}$ and prevents it from interacting with its receptor, which is known as receptor activator of NF- $\mathrm{KB}$ (RANK). Osteoclast differentiation is stimulated by a wide variety of hormones and cytokines, including 1,25-dihydroxyvitamin $\mathrm{D}_{3}$, parathyroid hormone, tumour necrosis factor (TNF) $\alpha$, interleukin (IL) 1, IL6, and IL1 1. ${ }^{6}$ Most of these agents are thought primarily to stimulate osteoclast differentiation indirectly by inducing bone marrow stromal cells or osteoblasts, which support osteoclast differentiation, to increase the production of RANKL, and/ or decrease the production of OPG. ${ }^{2} 8$

Abundant mature osteoclasts were found at the bonepannus junctions in RA. In addition to the bone marrow stroma, osteoclast precursors are also abundant in the hyperplastic synovial tissue. ${ }^{9}$ As a typical histopathological feature of RA, a hyperplastic and hypercellular synovial membrane is built up in which lymphocytes, macrophage-like cells, and fibroblast like cells accumulate. Several studies have shown that both RANKL and its receptor RANK are expressed on cells of the RA synovial membrane, including T cells. ${ }^{10}{ }^{11}$ Activated $\mathrm{T}$ cells have long been associated with the increased osteoclast formation and the accelerated bone resorption characteristic of inflammatory conditions. ${ }^{12} 13$ Recently, evidence has accumulated suggesting that $\mathrm{T}$ cells stimulate osteoclast formation by producing the key osteoclastogenic cytokine, RANKL. ${ }^{11}{ }^{14}{ }^{15}$ However, the mechanism(s) leading to up regulation of T cell RANKL production under inflammatory conditions remains unknown.

The molecular players in RA are still poorly understood. Proinflammatory cytokines, in particular TNF $\alpha$ and ILl, have proved to be major contributors to this disease. Recently, it was demonstrated that IL18 might participate in the bone and cartilage destruction of RA. ${ }^{16-19}$ It was also suggested that IL18 has an important role in inflammation and joint destruction in RA through $\mathrm{T}$ cells and macrophages, but not directly through fibroblast-like synoviocytes because of their lack of functional IL18 receptor (IL18R). ${ }^{20}$ Here we first reported that IL18, ILl, or TNF $\alpha$ indirectly stimulates osteoclastogenesis through up regulation of RANKL production from RA synovial T cells. The data presented in this paper

Abbreviations: ELISA, enzyme linked immunosorbent assay; FCS, fetal calf serum; GM-CSF, granulocyte monocyte-colony stimulating factor; IFN $\gamma$, interferon $\gamma ;$ IL, interleukin; M-CSF, monocyte/macrophagecolony stimulating factor; $\alpha-M E M, \alpha$-minimal essential medium; $M F I_{,}$ mean fluorescence intensity; OPG, osteoprotegerin; PBS, phosphate buffered saline; PHA, phytohaemagglutinin; RA, rheumatoid arthritis; RANK, receptor activator of NF- $\kappa B$; RANKL, receptor activator of NF- $\kappa B$ ligand; $T N F \alpha$, tumour necrosis factor $\alpha$; TRAP, tartrate resistant acid phosphatase 

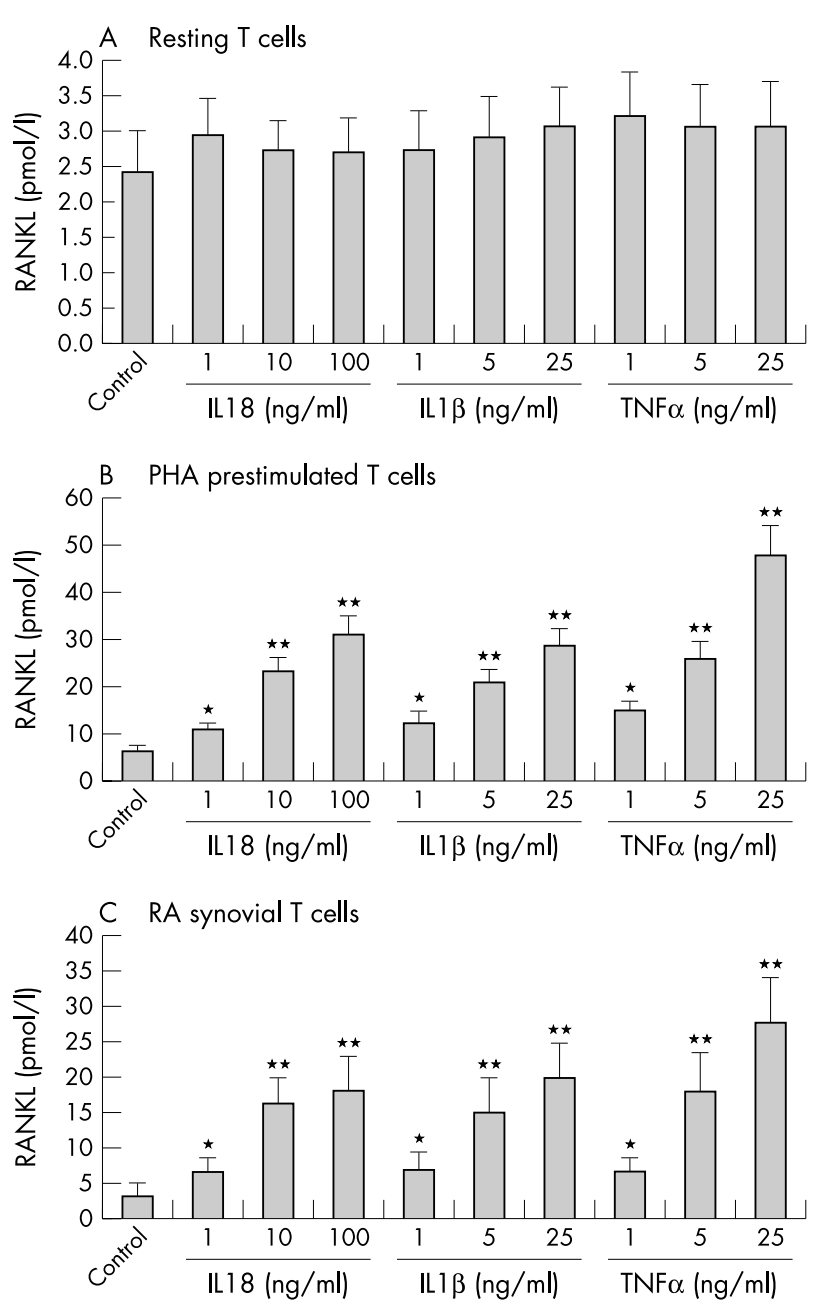

Figure 1 Soluble RANKL production in cultured human T cells in the presence of IL18, IL1 $\beta$, or TNF $\alpha$. (A) T cells were isolated from the peripheral blood of healthy donors. (B) T cells were isolated from the peripheral blood of healthy donors, and then simulated with $2 \mu \mathrm{g} / \mathrm{ml}$ PHA and $0.5 \mathrm{ng} / \mathrm{ml}$ IL2 for 24 hours. (C) T cells were isolated from the synovium of patients with RA. Cells were cultured in quadruplicate. The supernatants were harvested after 48 hours' incubation. RANKL levels were determined by ELISA. Data represent mean (SD). ${ }^{*} p<0.05$, ${ }^{* *} p<0.01$ compared with control group. Results shown are representative of four independent experiments.

further extend our knowledge of the roles of proinflammatory cytokines in erosion of bone and cartilage in RA.

\section{MATERIALS AND METHODS Reagents}

Fetal calf serum (FCS), streptomycin, penicillin, L-glutamine, RPMI-1640, $\alpha$-minimal essential medium ( $\alpha$-MEM) and phosphate buffered saline (PBS) free of $\mathrm{Ca}^{2+}$ and $\mathrm{Mg}^{2+}$ were purchased from Gibco (Invitrogen Corporation, New York, USA). Recombinant human TNF $\alpha$, ILI $\beta$, IL2, M-CSF, OPG, and monoclonal antibody to RANKL and isotype control mouse IgG2B were bought from R\&D System (Minneapolis, MN, USA). The sources of other reagents were as follows: phytohaemagglutinin (PHA) and recombinant human soluble RANKL (Wako, Osaka, Japan); Ficoll-Paque with specific density $1.077 \mathrm{~g} / \mathrm{ml}$ (Amersham Biosciences, Uppsala, Sweden); recombinant human IL18 (MBL, Nagoya, Japan); pan T cell isolation kit (MACS; Miltenyi Biotec, Auburn, CA, USA); and phycoerythrin conjugated goat $\mathrm{F}\left(\mathrm{ab}^{\prime}\right)_{2}$ fragment antimouse IgG (H+L) (Immunotech, Marseille Cedex, France).
Isolation and purification of peripheral blood T cells and synovial membrane T cells

Briefly, heparinised peripheral blood was collected from healthy volunteers. Peripheral blood mononuclear cells were isolated by standard Ficoll-Paque density gradient centrifugation, and then were washed with PBS. Enriched $\mathrm{CD}^{+} \mathrm{T}$ cells were purified by magnetic depletion of non-T cells, using the MACS indirect magnetic labelling system according to the manufacturer's instructions.

The fresh synovial samples were obtained at the time of total knee replacement or knee joint synovectomy performed on six female patients with RA (age range 50-78 years), whose diagnosis met the American College of Rheumatology (formerly, the American Rheumatism Association) 1987 revised criteria for the disease. ${ }^{21}$ After careful removal of the adipose tissue, synovial samples were minced on tissue culture plates, digested with collagenase $(1 \mathrm{mg} / \mathrm{ml})$ in RPMI1640 supplemented with $10 \%$ FCS, incubated for 6 hours at $37^{\circ} \mathrm{C}$, filtered through a $70 \mu \mathrm{m}$ nylon mesh, and centrifuged. The cell pellet was resuspended in RPMI-1640/10\% FCS at a density of $1 \times 10^{6}$ cells $/ \mathrm{ml}$, and seeded onto culture plates. After 6 hours' culture, non-adherent cells were harvested, and were used to isolate T cells by Ficoll-Paque density gradient centrifugation and the MACS system, as described above.

All samples were obtained after informed consent had been signed, and this study was approved by the local institutional ethics committee.

\section{Stimulation of peripheral blood T lymphocytes}

In some instances, T lymphocytes $\left(2 \times 10^{6}\right.$ cells $\left./ \mathrm{ml}\right)$, isolated from the peripheral blood of health donors, were incubated in RPMI-1640 containing 10\% FCS, $50 \mu \mathrm{g} / \mathrm{ml}$ streptomycin, and $50 \mathrm{U} / \mathrm{ml}$ penicillin at $37^{\circ} \mathrm{C}$ in $5 \% \mathrm{CO}_{2} / 95 \%$ air in a humidified incubator, in the presence of $2 \mu \mathrm{g} / \mathrm{ml}$ PHA and $0.5 \mathrm{ng} / \mathrm{ml} \mathrm{IL2}$ for 24 hours.

\section{Generation of human osteoclasts in vitro}

Poietic human osteoclast precursors obtained from BioWhittaker Inc (Walkersville, MD, USA) were isolated from the bone marrow of healthy donors by density gradient centrifugation, immunoaffinity purification, and selective culturing techniques (for detailed information about the precursors please visit: www.cambrex.com/bioproducts; accessed August 2004). To induce osteoclast differentiation in vitro, the osteoclast precursors were plated at a density of $4 \times 10^{4}$ cells per well in a final volume of $0.4 \mathrm{ml}$, using eight well chamber slides (Nalge Nunc International Corp, Naperville, IL, USA) and cultured in $\alpha$-MEM supplemented with $10 \%$ heat inactivated FCS, penicillin $(50 \mathrm{U} / \mathrm{ml})$, streptomycin $(50 \mathrm{mg} / \mathrm{ml})$, and $33 \mathrm{ng} / \mathrm{ml} \mathrm{M-CSF}$, at $37^{\circ} \mathrm{C}$ in $5 \% \mathrm{CO}_{2} /$ $95 \%$ air, in a humidified incubator. As indicated, the cultures were further stimulated with $30 \mathrm{ng} / \mathrm{ml}$ soluble RANKL or $10 \mathrm{ng} / \mathrm{ml} \mathrm{TNF} \alpha$, or cocultured with T cells $\left(1 \times 10^{5}\right.$ cells per well) in the presence of different cytokines. The cells were fed by replacing half the medium twice weekly with fresh stimuli.

After 7-10 days of culture, cells were fixed and stained for tartrate resistant acid phosphatase (TRAP), using a commercial kit (Sigma, St Louis, MO, USA) according to the manufacturer's instructions, and omitting counterstaining with haematoxylin. According to two very specific markers of authentic osteoclasts, we have thus defined multinucleated (more than or equal to three nuclei) TRAP positive cells as mature osteoclasts, which could form resorption pits on dentine slices, verifying these cells as functional osteoclasts.

\section{Resorption pit assay}

The ability of osteoclasts to resorb pits was assessed by generating mature osteoclasts (as described above) on ivory 

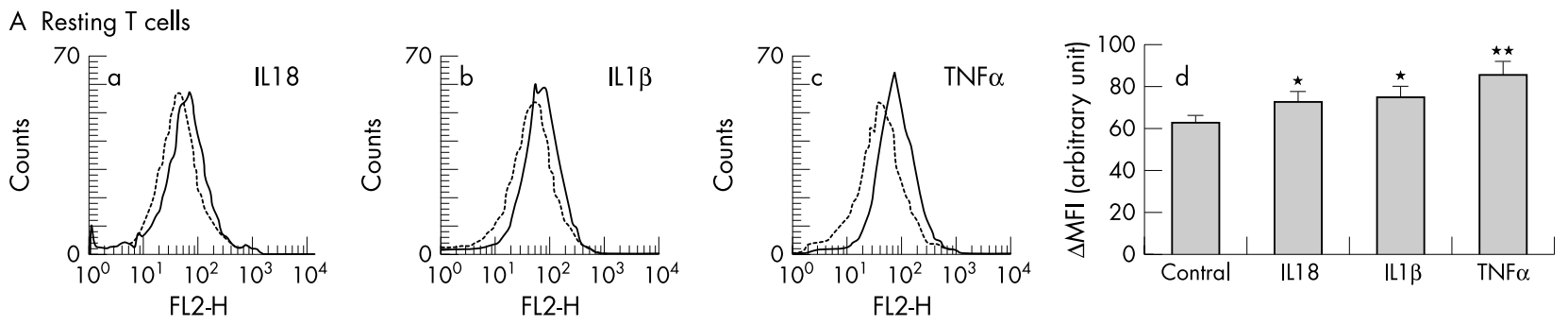

B PHA prestimulated T cells
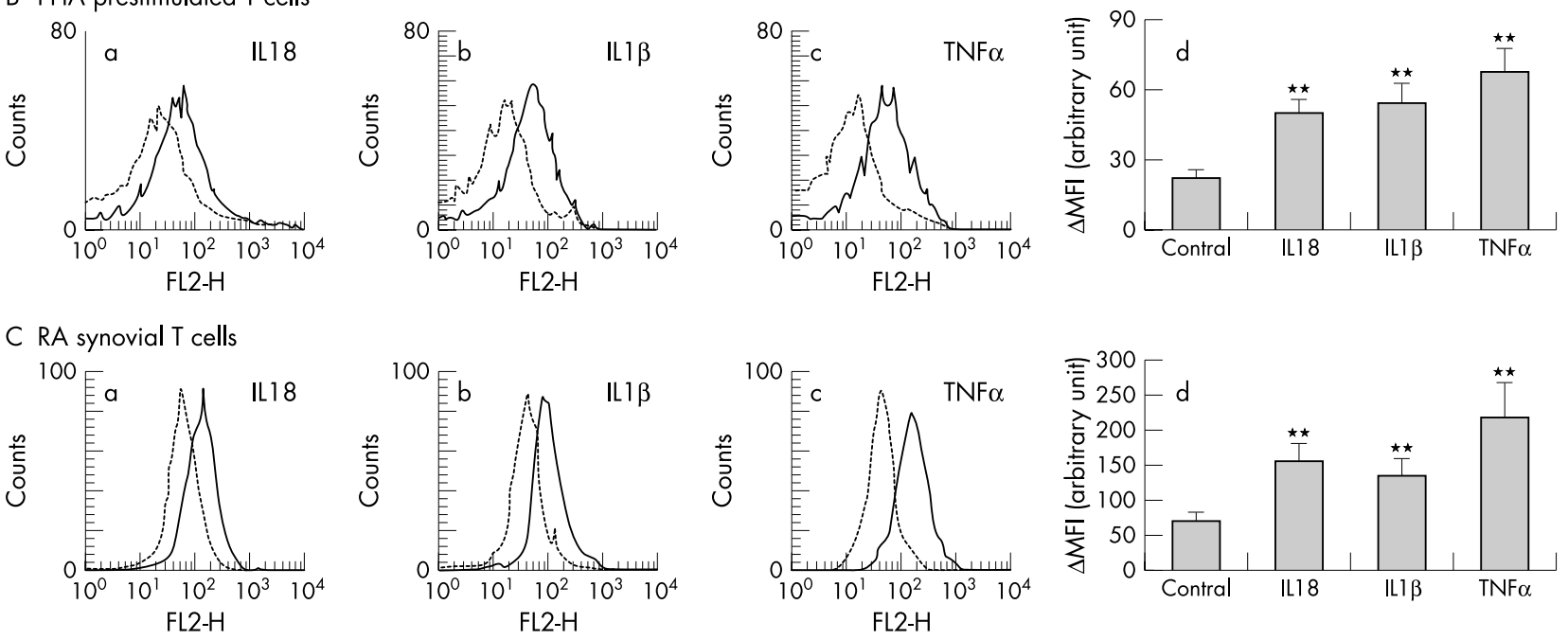

Figure 2 Membrane bound RANKL expression in cultured human T cells in the presence of IL18, IL1 $\beta$, or TNF $\alpha$. RANKL expression on T cells was analysed by flow cytometry. A representative histogram overlay of $10 \mathrm{ng} / \mathrm{ml} \mathrm{IL18} \mathrm{(a),} 10 \mathrm{ng} / \mathrm{ml} \mathrm{IL1} \beta$ (b), or $10 \mathrm{ng} / \mathrm{ml} \mathrm{TNF} \alpha$ (c) stimulated (solid line) and unstimulated (broken line) cells. Changes in $\triangle$ MFI (difference between the mean fluorescence intensity (MFI) of positive staining and the MFI of the isotype matched negative control) are also shown (d). ${ }^{*} p<0.05,{ }^{* *} p<0.01$ compared with the control group. See fig 1 for other information.

dentine slices (Wako, Osaka, Japan), in 96 well plates. After 15 days of culture, dentine slices were washed with PBS and incubated for 18 hours in $0.25 \mathrm{M}$ ammonium hydroxide, followed by sonication in PBS for 30 seconds. Dentine slices were washed with PBS and stained in Mayer's haematoxylin solution for 2 minutes, and pits were photographed under reflected light with a digital high fidelity microscope VH-8000 (Keyence, Osaka, Japan). The total pit areas were measured in four randomly selected areas of each dentine slice by an image analysis system (Image Gauge version 4.0, Fuji Photo Film Co, Ltd, Tokyo, Japan).

\section{Measurement of cytokines}

Purified T cells were plated at a density of $1.5 \times 10^{6}$ cells $/ \mathrm{ml}$ onto 96 well plates, and cultured in $\alpha$-MEM supplemented with $10 \%$ heat inactivated FCS, $50 \mathrm{U} / \mathrm{ml}$ penicillin, and $50 \mathrm{mg} / \mathrm{ml}$ streptomycin. Where indicated, cultures were stimulated with different concentrations of IL18 (1-100 ng/ $\mathrm{ml})$, ILl $\beta(1-25 \mathrm{ng} / \mathrm{ml})$, or TNF $\alpha(1-25 \mathrm{ng} / \mathrm{ml})$. After 48 hours' incubation, the supernatants were harvested and stored at $-40^{\circ} \mathrm{C}$. Cytokines were measured by commercially available enzyme immunoassay kits following the manufacturer's instructions. The human soluble RANKL enzyme linked immunosorbent assay (ELISA) kits were purchased from Biomedica-Gruppe (Vienna, Austria), human interferon $\gamma($ IFN $\gamma)$, human M-CSF and human granulocyte monocytecolony stimulating factor (GM-CSF) ELISA kits from R\&D System (Minneapolis, MN, USA), and human OPG ELISA kits from BioVendor Laboratory Medicine, Inc (Brno, Czech Republic). Their sensitivities were as follows: RANKL $0.4 \mathrm{pmol} / \mathrm{l}$; IFN $\gamma 8 \mathrm{pg} / \mathrm{ml} ; \mathrm{M}-\mathrm{CSF}<9 \mathrm{pg} / \mathrm{ml} ;$ GM-CSF $3 \mathrm{pg} /$ $\mathrm{ml}$; and $\mathrm{OPG} 30 \mathrm{pg} / \mathrm{ml}$.

\section{Flow cytometric analysis}

For analysis of membrane bound RANKL expression, purified $\mathrm{T}$ cells were plated onto six well plates at $5 \times 10^{5}$ cells $/ \mathrm{ml}$, and stimulated with $10 \mathrm{ng} / \mathrm{ml} \mathrm{ILl8,} 10 \mathrm{ng} / \mathrm{ml} \mathrm{ILl} \beta$, or $10 \mathrm{ng} / \mathrm{ml}$ TNF $\alpha$ for 24 hours.

Cells were harvested and then treated with $20 \mu \mathrm{g} / \mathrm{ml}$ mouse monoclonal antibody to RANKL or mouse IgG2B (isotype matched control) as primary antibody at $4^{\circ} \mathrm{C}$ for 35 minutes. After washing with PBS, cells were then incubated for 35 minutes with a phycoerythrin conjugated goat antimouse antibody $(5 \mu \mathrm{g} / \mathrm{ml})$ at $4^{\circ} \mathrm{C}$ in the dark. Samples were assayed with a FACSCalibur (Becton Dickinson, Franklin Lakes, NJ, USA). Analysis was performed using CELLQuest software (Becton Dickinson). Data are presented as the difference $(\Delta)$ between the mean fluorescence intensity (MFI) of positive staining and the MFI of an isotype matched negative control.

\section{Osteoprotegerin neutralisation}

For OPG neutralisation experiments, OPG was added to wells at a concentration of $2 \mu \mathrm{g} / \mathrm{ml}$ before the addition of $\mathrm{T}$ cells and the indicated proinflammatory cytokine. The concentration of OPG was found to completely neutralise osteoclast formation induced by a saturating dose of RANKL ( $100 \mathrm{ng} / \mathrm{ml}$ ) and $50 \mathrm{ng} / \mathrm{ml}$ of M-CSF, verifying its biological activity. ${ }^{22}$

\section{Statistical analysis}

Data were expressed as the mean (SD). Results shown are representative of three to four independent experiments. Multigroup mean values were compared using analysis of variance, and two group mean values using an unpaired two 


\section{A Negative control $(\mathbf{x} 40)$}

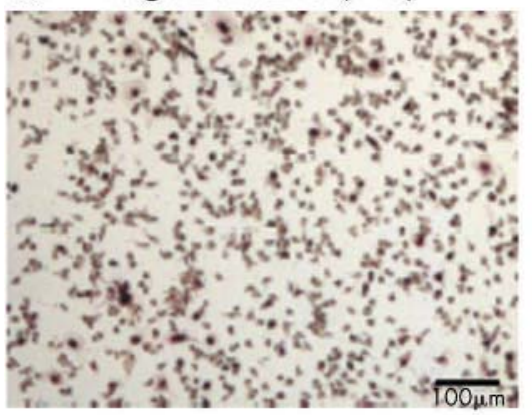

RANKL (x 100)

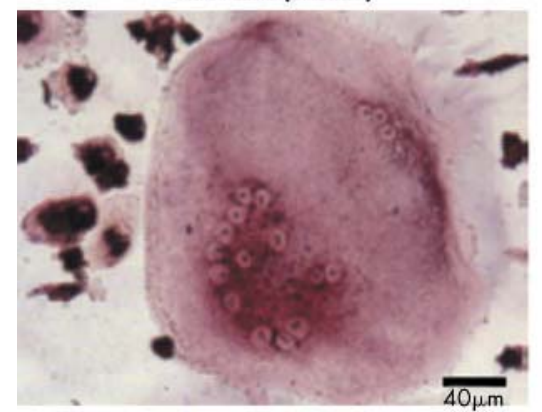

T cells + TNF $\alpha$ (x40)

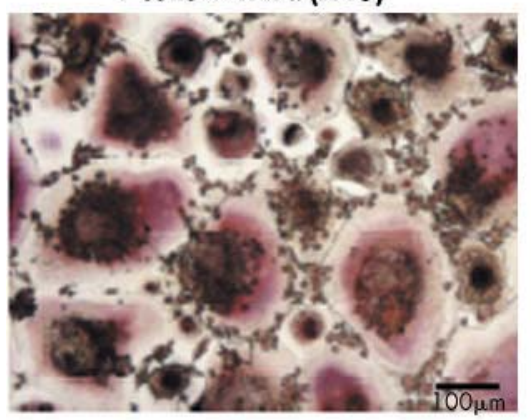

RANKL (x40)

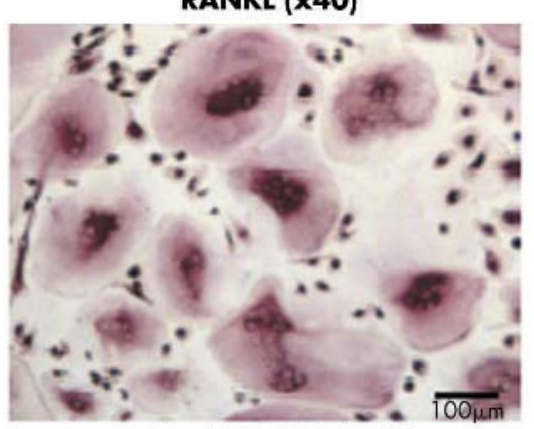

T cells + ILI8 (x40)
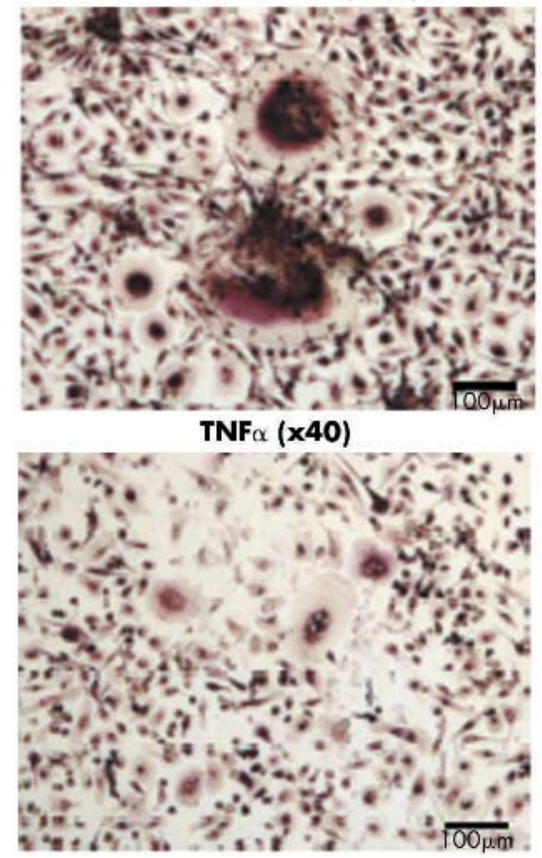

T cells ( $x 40)$

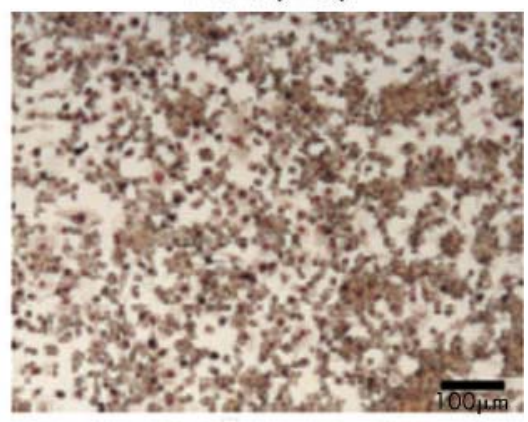

T cells + ILI $\beta(x 40)$

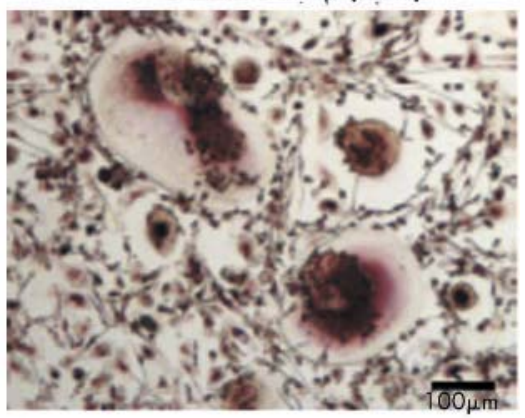

B

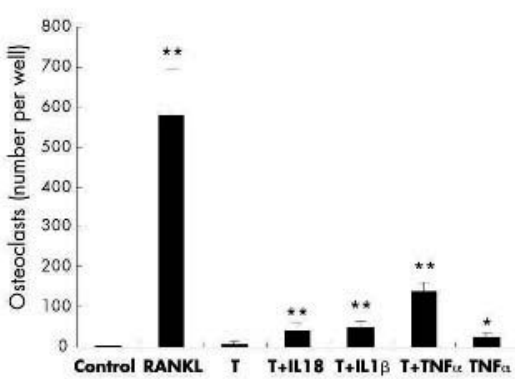

Figure 3 Osteoclast formation induced from the precursor cells in different conditions. All the cultures were stimulated with $33 \mathrm{ng} / \mathrm{ml} \mathrm{M-CSF}$. With the indicated conditions, the cultures were further stimulated with $30 \mathrm{ng} / \mathrm{ml}$ soluble RANKL or $10 \mathrm{ng} / \mathrm{ml} \mathrm{TNF} \alpha$, or cocultured with PHA prestimulated T cells in the presence of $10 \mathrm{ng} / \mathrm{ml}$ IL18, IL1 $\beta$, or TNF $\alpha$. After 7-10 days of culture, cells were fixed and stained for TRAP. TRAP positive giant cells with numerous ( $\geqslant 3$ ) unstained nuclei were considered as mature osteoclasts. See scale bar in each picture. In (B) T indicates PHA prestimulated T cells. ${ }^{*} \mathrm{p}<0.05,{ }^{* *} \mathrm{p}<0.01$ compared with the group with T cells only.

tailed Student's $t$ test. Values of $\mathrm{p}<0.05$ were considered significant.

\section{RESULTS}

Production of soluble RANKL from T cells

ILl8 (1-100 ng/ml), IL1 $\beta$ ( $1-25 \mathrm{ng} / \mathrm{ml})$, or TNF $\alpha(1-25 \mathrm{ng} /$ $\mathrm{ml})$ had no significant effects on the soluble RANKL production from resting $\mathrm{T}$ cells (fig 1A). In PHA prestimulated T cells (fig 1B) and RA synovial T cells (fig 1C), IL18, IL1 $\beta$, or TNF $\alpha$ increased the production of soluble RANKL in a dose dependent manner. Compared with the efficacy of $100 \mathrm{ng} / \mathrm{ml} \mathrm{ILl8,} 25 \mathrm{ng} / \mathrm{ml}$ ILl $\beta$ showed equivalent potency and $25 \mathrm{ng} / \mathrm{ml} \mathrm{TNF} \alpha$ slightly more potent efficacy.

\section{Expression of membrane bound RANKL on T cells}

As the molecular weights of IL18, IL1 $\beta$, and TNF $\alpha$ are similar, we applied the same concentration $(10 \mathrm{ng} / \mathrm{ml})$ of these cytokines. In the resting $\mathrm{T}$ cells, all these cytokines just marginally up regulated the expression of membrane bound RANKL (fig 2A). In PHA prestimulated T cells (fig 2B) and RA synovial T cells (fig 2C), IL18, IL1 $\beta$, or TNF $\alpha$ significantly increased the expression of membrane bound RANKL after 24 hours' stimulation. There was no significant difference in the RANKL expression levels on activated $\mathrm{T}$ cells between IL18 and ILl $\beta$ stimulation. T cells stimulated by TNF $\alpha$ expressed more RANKL than IL18. The enhanced expression levels of RANKL on activated $\mathrm{T}$ cells were sustained for 2 days but returned to the same level as the control groups after 72 hours' stimulation with ILl8, ILl $\beta$, or TNF $\alpha$ (data not shown).

\section{Null production of M-CSF, GM-CSF, IFN $\gamma$, or OPG from T cells}

IL18, IL1 $\beta$, and TNF $\alpha$ all failed to induce the production of M-CSF, GM-CSF, IFN $\gamma$, and OPG in resting T cells, PHA prestimulated T cells, or RA synovial T cells (data not shown).

\section{Induction of osteoclast formation}

TRAP positive giant cells with numerous unstained nuclei were observed in the cultured osteoclast precursors stimulated with M-CSF and soluble RANKL (fig 3A), which were able to form resorption lacunae on dentine slices (fig $4 \mathrm{~A}$ ). In the presence of 
A

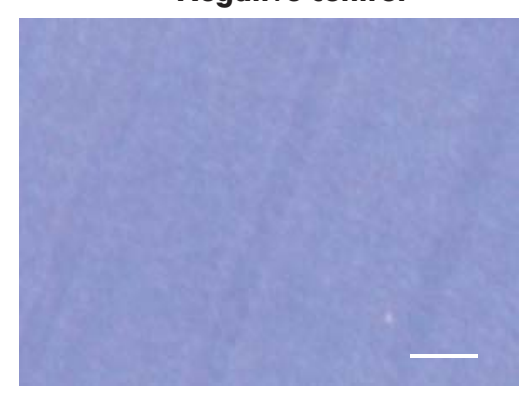

T cells + IL18

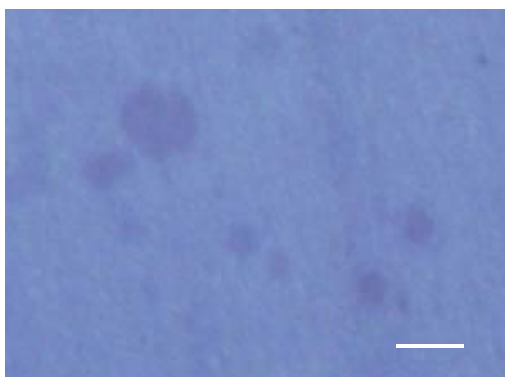

TNF $\alpha$

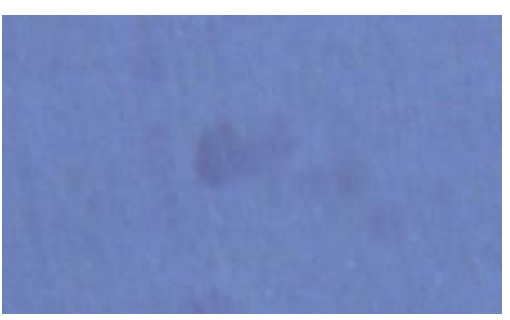

RANKL

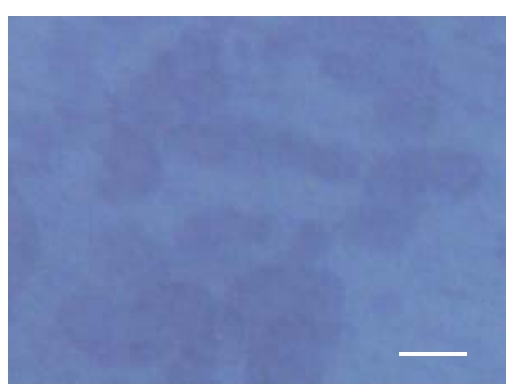

T cells + IL1 $\beta$

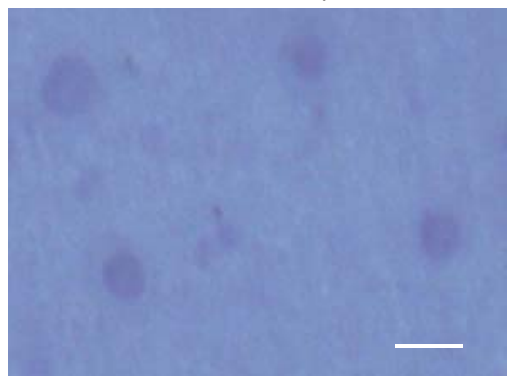

B

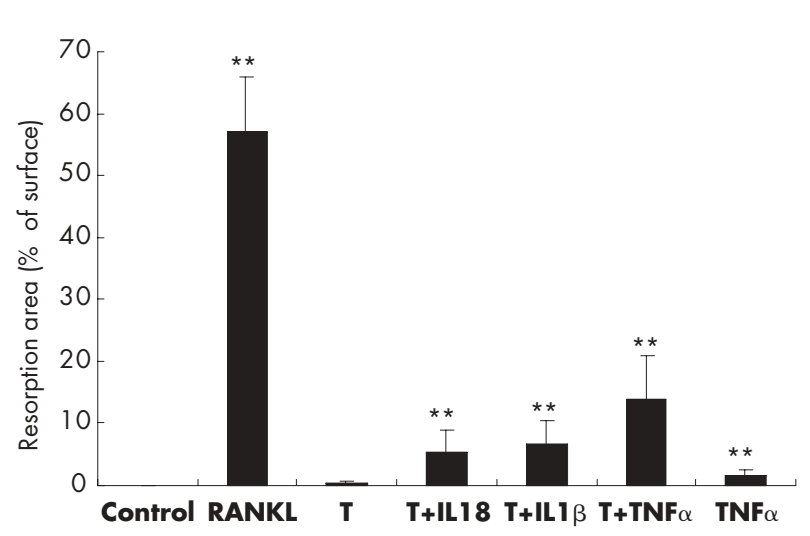

T cells

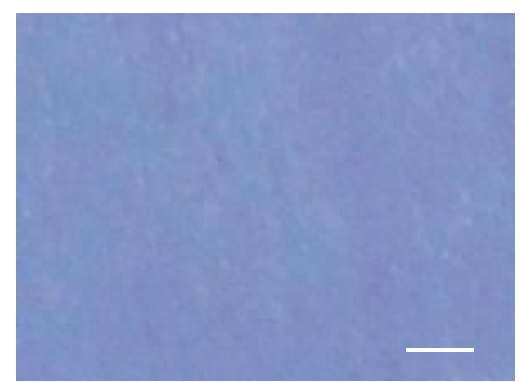

T cells $+\mathbf{T N F} \alpha$

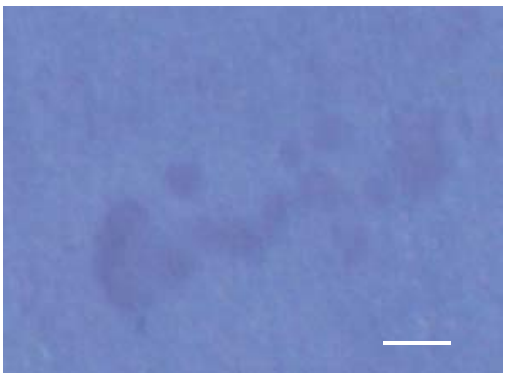

Figure 4 Resorption activity of induced osteoclasts on dentine slices. The osteoclasts were induced as in fig 3. Dentine slices were stained in Mayer's haematoxylin solution, and pits were photographed under a reflected light microscope (A). Scale bar $100 \mu \mathrm{m}$. The total pit areas were measured in four randomly selected areas of each dentine slice using an image analysis system (B). In (B) T indicates PHA prestimulated T cells. ${ }^{* *} \mathrm{p}<0.01$ compared with the group with T cells only.

M-CSF, IL18, IL1 $\beta$, or TNF $\alpha$ significantly stimulated osteoclast formation through PHA prestimulated T cells (fig 3) or RA synovial T cells (fig 5); TNF $\alpha$ had the most marked effect and ILl8 was as effective as ILl $\beta$. ILl8, ILl $\beta$, or TNF $\alpha$ also significantly increased the bone resorption area formed by cocultured cells (figs 4 and 6), and the area difference among groups was consistent with the number of osteoclasts.

Recent data show that TNF can stimulate osteoclastogenesis independently of RANKL, ${ }^{23}$ so we also compared the effect of $\mathrm{TNF} \alpha$ on osteoclast formation in the absence or presence of activated $\mathrm{T}$ cells. As a result, more osteoclasts were formed in the presence of both $\mathrm{TNF} \alpha$ and activated $\mathrm{T}$ cells than with TNF $\alpha$ alone (fig 3). Neither IL18 nor ILl $\beta$ induced osteoclast differentiation directly in the absence of activated $\mathrm{T}$ cells (data not shown).

\section{Inhibitory effect of OPG}

When OPG was added before the coculture of osteoclast precursors and PHA prestimulated $\mathrm{T}$ cells, the osteoclast formation enhanced by IL18 or IL1 $\beta$ was abrogated while the $\mathrm{TNF} \alpha$ enhanced osteoclast formation was suppressed more than $60 \%$ (data not shown).

\section{DISCUSSION}

RANKL expression in T cells was discovered by Wong et al in $1997,{ }^{4}$ and was designated TRANCE at first. They further demonstrated that RANKL mRNA is constitutively expressed in memory, but not naive, T cells. ${ }^{24}$ Upon T cell receptor/antiCD3 stimulation, RANKL mRNA and surface protein expression are rapidly up regulated in $\mathrm{CD}^{+}$and $\mathrm{CD} 8^{+} \mathrm{T}$ cells, and the enhanced expression of RANKL in $\mathrm{CD}^{+} \mathrm{T}$ cells is suppressed by IL4. ${ }^{24}$ In the present study we found that IL18, IL1 $\beta$, or TNF $\alpha$ had no significant effect on RANKL production in resting $\mathrm{T}$ cells, but all of them significantly increased production of both soluble and membrane bound RANKL in PHA prestimulated T cells or RA synovial T cells. We also found that the increased expression of membrane bound RANKL in activated $\mathrm{T}$ cells was sustained for 2 days, 
A
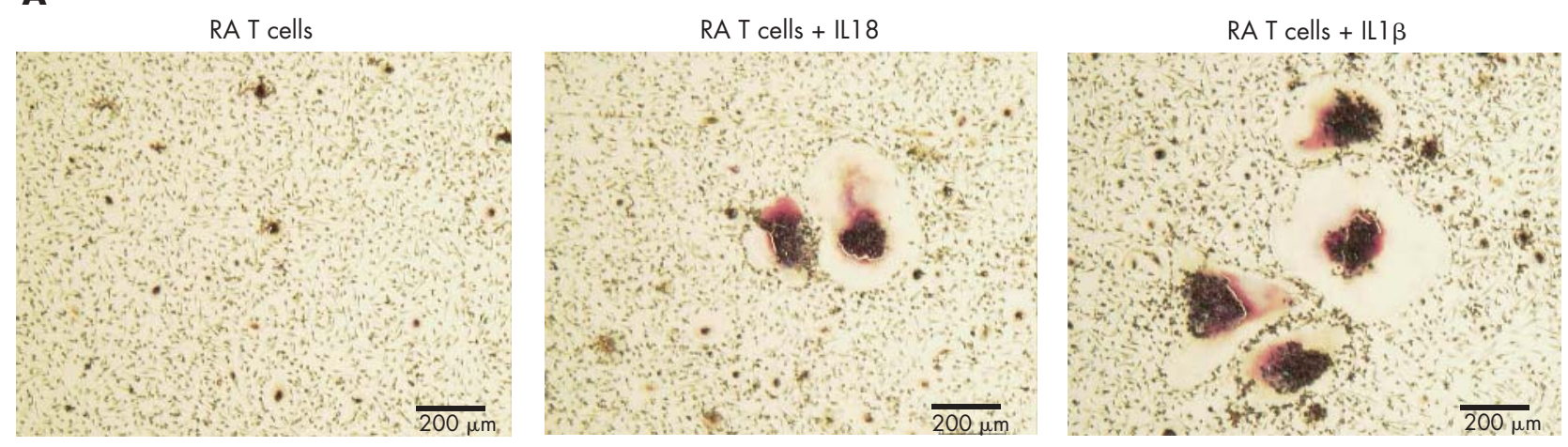

RA T cells + TNF $\alpha$

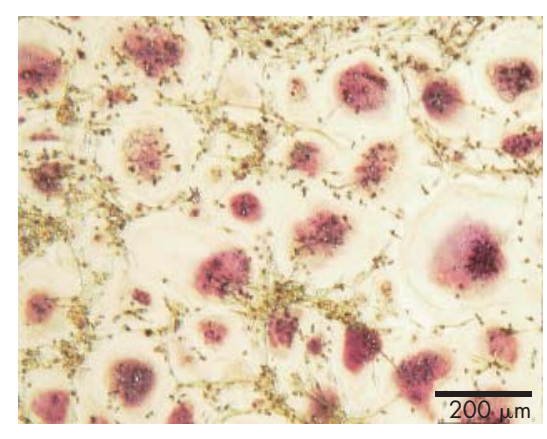

B

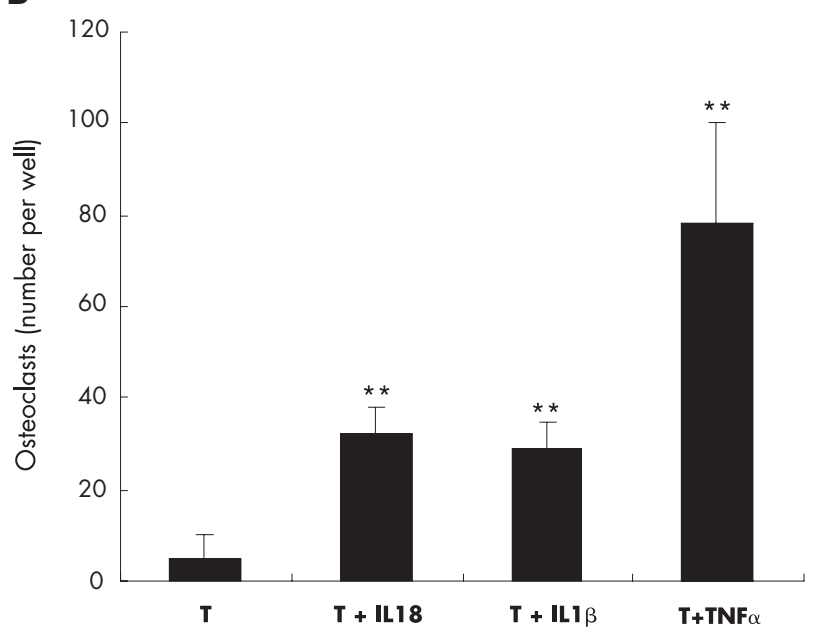

Figure 5 Osteoclast formation induced from the precursor cells cocultured with RA synovial T cells. All the cultures were stimulated with $33 \mathrm{ng} / \mathrm{ml}$ M-CSF. With the indicated conditions, the cultures were further stimulated with $10 \mathrm{ng} / \mathrm{ml} \mathrm{IL18,} \mathrm{IL1} \beta$, or TNF $\alpha$. Scale bar $200 \mu \mathrm{m}$. In (B) T indicates RA synovial T cells. ${ }^{* *} \mathrm{p}<0.01$ compared with the group with T cells only.

and returned to the baseline level after 72 hours' stimulation with IL18, IL1 $\beta$, or TNF $\alpha$. Kotake et al found that the expression of RANKL mRNA by reverse transcriptasepolymerase chain reaction was maximal on day 1 and the high level was only sustained until day 2 in T cells after PHA stimulation. ${ }^{11}$ Josien et al reported that the maximal level of membrane bound RANKL after the initial $\mathrm{T}$ cell activation was 48 hours and the high levels of RANKL expression were sustained until 96 hours. ${ }^{24}$ Our findings were consistent with these data. $\mathrm{CD}^{+} \mathrm{CD}^{+} 5 \mathrm{RA}^{+} \mathrm{T}$ cells constitutively expressed IL18R $\beta$ mRNA but not IL18R $\alpha$ mRNA. PHA primed and IL2 stimulated $\mathrm{T}$ cells clearly expressed mRNA for IL18R $\alpha-$ IL18R $\beta$ and IL1RI-IL1R accessory protein. ${ }^{25}$ These data can partially explain why IL18 or ILI $\beta$ failed to induce RANKL production in resting $\mathrm{T}$ cells, but successfully induced it in PHA prestimulated T cells.

RANKL binding to the RANK expressed on haematopoietic progenitors activates a signal transduction cascade that leads to osteoclast differentiation in the presence of the survival factor M-CSF. Moreover, RANKL stimulates the bone resorbing activity of mature osteoclasts through RANK. RANKL seems to be the pathogenetic principle that causes bone destruction in arthritis. Inhibition of RANKL function by the natural decoy receptor OPG prevents bone loss in postmenopausal osteoporosis and cancer metastases and completely blocks bone loss and crippling in various rodent models of arthritis. RANKL also regulates $\mathrm{T}$ cell/dendritic cell communication, dendritic cell survival, and lymph node organogenesis. ${ }^{26}$ Moreover, production of RANKL by activated T cells directly controls osteoclastogenesis and bone remodelling.

Recently, accumulating evidence has shown that activated $\mathrm{T}$ cells can support osteoclast formation. In 1999 Kong et al reported that both the supernatant of activated $\mathrm{T}$ cells and paraformaldehyde fixed T cells, which were stimulated with anti-CD $3 \epsilon$ plus anti-CD28 for 4 days, directly triggered osteoclastogenesis from mouse bone marrow precursors or newborn RANKL ${ }^{-/-}$mouse spleen cells in the presence of $\mathrm{M}-\mathrm{CSF}$, which was abolished by the addition of OPG. ${ }^{14}$ In addition, OPG administration reduced bone destruction by activated RANKL-producing $\mathrm{T}$ cells in mice with adjuvant arthritis, without affecting inflammatory status. ${ }^{14}$ In the same year, another group demonstrated that IL2 failed to induce RANKL mRNA in human T cells, but concanavalin A alone or in combination with anti-CD3 increased RANKL mRNA after 24 hours' treatment. They further demonstrated that concanavalin A alone or in combination with anti-CD3 activated $\mathrm{T}$ cells induced osteoclast formation from adherent murine spleen cells. ${ }^{15}$ Moreover, PHA activated human T cells expressing RANKL can induce osteoclastogenesis from autologous peripheral monocytes, which can be blocked by dose dependent inhibition with OPG. ${ }^{11}$ In a recent study it has been confirmed that transgenic overexpression of RANKL in $\mathrm{T}$ cells restores osteoclastogenesis in a $\mathrm{RANKL}^{-/-}$background and partially restores normal bone marrow cavities. ${ }^{27}$

So these data showed that systemic activation of $\mathrm{T}$ cells leads to bone loss, indicating that through their production of RANKL, T cells are crucial mediators of bone loss in vivo. This 


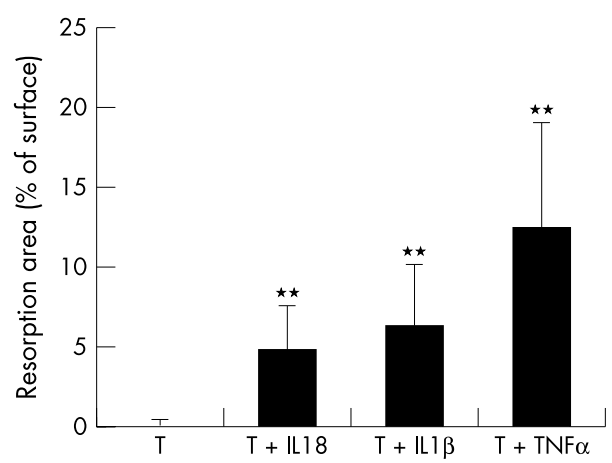

Figure 6 Bone resorption activity of osteoclasts induced by RA synovial T cells. The osteoclasts were induced as in fig 5. The total pit areas were measured in four randomly selected areas of each dentine slice using an image analysis system. T indicates RA synovial T cells. ${ }^{* *} \mathrm{p}<0.01$ compared with the group with T cells only.

was further supported by the report in 2003 that $\mathrm{T}$ cells are an essential mediator of IL7 induced bone loss in vivo. ${ }^{28}$ Weitzmann et al found that both PHA activated $\mathrm{CD}^{+}$and $\mathrm{CD}^{+} \mathrm{T}$ cells stimulated human osteoclast formation in vitro, ${ }^{29}$ but Choi et al thought that activated $\mathrm{CD}^{+} \mathrm{T}$ cells suppressed osteoclastogenesis. ${ }^{30}$

In the present study, we found that IL18, ILl $\beta$, or TNF $\alpha$ stimulated osteoclast formation through PHA prestimulated $\mathrm{T}$ cells rather than resting $\mathrm{T}$ cells, and OPG inhibited the osteoclastogenesis. To extend these studies to human patients with arthritis, we isolated T cells from RA synovium, and we found that the above cytokines also stimulated osteoclastogenesis through RA synovial $\mathrm{T}$ cells, which was also inhibited by OPG. These data are helpful in understanding the mechanisms of accelerated osteoclastogenesis and bone loss in RA.

Recently, IL18 was considered to be an inhibitory factor of osteoclastogenesis, because it was found to inhibit osteoclast formation in the coculture of mouse osteoblasts and haematopoietic cells of spleen or bone marrow origin, in the absence of M-CSF. The inhibitory effect of IL18 was limited to the early phase of the coculture, which coincides with proliferation of haematopoietic precursors. ${ }^{31}$ Neutralising antibodies to GM-CSF were able to rescue IL18 inhibition of osteoclast formation, whereas neutralising antibodies to IFN $\gamma$ could not. ${ }^{31}$ It was further demonstrated, by using GM-CSF deficient mice, that IL18 inhibited osteoclast formation through $\mathrm{T}$ cell production of GM-CSF. ${ }^{32}$

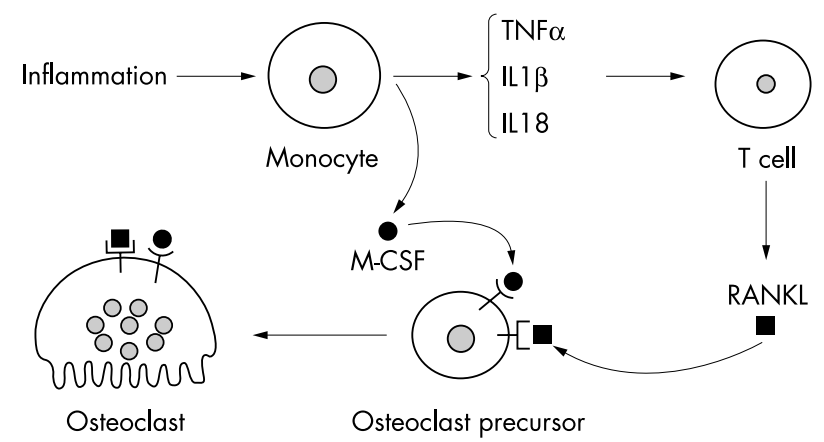

Figure 7 A schematic diagram of IL18, IL $1 \beta$, or TNF $\alpha$ indirectly stimulating osteoclastogenesis through $\mathrm{T}$ cells in synovitis. In RA synovium, accumulated monocytes/macrophages (and synovial fibroblasts) produce proinflammatory cytokines, such as TNF $\alpha, I L 1 \beta$, and IL18. These cytokines enhance RANKL production from activated T cells, and then induce osteoclast precursors to differentiate into mature osteoclasts.
However, considerable evidence supports the fact that IL18 facilitates bone destruction in RA. For example, administration of IL18 to collagen/incomplete Freund's adjuvant immunised DBA/l mice facilitated the development of an erosive, inflammatory arthritis. ${ }^{16}$ Mice treated with IL18 had a significantly higher incidence and more severe disease (synovial hyperplasia, cellular infiltration, and cartilage erosion) than controls in collagen induced arthritis in DBA/l mice. ${ }^{17}$ Suppression of joint swelling was noted in murine streptococcal cell wall induced arthritis after blockade of endogenous IL18. ${ }^{18}$ In the collagen induced arthritis model, mice lacking ILl8 had a markedly reduced incidence of arthritis compared with heterozygous or wild-type mice. This was accompanied by reduced articular inflammation and destruction, evident on histology. Treatment with ILl8 completely reversed the disease of the $1 \mathrm{~L} 18^{-1-}$ mice to that of the wild-type mice. ${ }^{19}$ Here, our data support the effect of IL18 on bone destruction in arthritis. We also found that IL18 failed to induce IFN $\gamma$ or GM-CSF production from activated T cells.

IFN $\gamma$ is an inhibitory factor of osteoclast formation. Although IL18 was also named IFN $\gamma$ inducing factor, IL12 is essential for IL18 to induce IFN $\gamma$ production from T cells. ${ }^{33}$ ILl8 $(500 \mathrm{ng} / \mathrm{ml})$ or ILl $\beta(10 \mathrm{ng} / \mathrm{ml})$ did not induce IFN $\gamma$ production either from resting $\mathrm{T}$ cells or from PHA prestimulated T cells. ${ }^{25} \mathrm{IL} 18$ ( $100 \mathrm{ng} / \mathrm{ml}$ ) also failed to induce IFN $\gamma$ production from anti-CD3 stimulated T cells. ${ }^{25}{ }^{33}$ In the present study IL18, IL1 $\beta$, or TNF $\alpha$ did not induce IFN $\gamma$ production from resting, PHA prestimulated, or RA synovial $\mathrm{T}$ cells. These results indicate that IL18, ILI $\beta$, or TNF $\alpha$ do not induce IFN $\gamma$ production from $\mathrm{T}$ cells to inhibit osteoclast differentiation in RA.

We found that IL18 did not induce GM-CSF production from $\mathrm{T}$ cells either, although Ogura et al reported that IL18 alone increased GM-CSF but not IFN $\gamma$ production from mouse spleen cells, and they also found that $300 \mathrm{ng} / \mathrm{ml} \mathrm{ILl} 8$ increased GM-CSF production in $\mathrm{CD}^{+}{ }^{+} \mathrm{T}$ cells but not in $\mathrm{CD}^{+}$ T cells. ${ }^{34}$ In their experiments, the cell density was $5 \times 10^{6} \sim$ $2 \times 10^{7}$ cells $/ \mathrm{ml}$. Here we used the purified T cells and the cell density or concentration of IL18 was not as high as in their study. Several reports also state that GM-CSF can stimulate osteoclast formation in vitro ${ }^{35-37}$ and in vivo. ${ }^{38}$ These data do not support the statement that GM-CSF mediates the inhibitory effect of IL18 on osteoclastogenesis.

Synovial T cell populations from rats or from patients with RA expressed RANKL, but not OPG. ${ }^{14}$ Consistent with these results, we found that OPG was not produced from resting or activated T cells despite stimulation with IL18, IL1 $\beta$, or TNF $\alpha$. Weitzmann et al reported that no M-CSF secretion was detected in unstimulated $\mathrm{T}$ cells, ${ }^{22}$ and stimulation of $\mathrm{T}$ cells by ILl $\alpha$ and TNF $\alpha$ failed to induce detectable levels of M-CSF. In line with this report, we also found that the level of M-CSF in the supernatants of cultured $\mathrm{T}$ cells was undetectable in various conditions.

In summary, our data show that IL18 enhanced both soluble and membrane bound RANKL production from PHA prestimulated $\mathrm{T}$ cells or RA synovial $\mathrm{T}$ cells, but did not induce IFN $\gamma$, GM-CSF, M-CSF, or OPG production. IL18 stimulated osteoclast formation through activated $\mathrm{T}$ cells which was stopped by OPG, and was as effective as ILl $\beta$, but less potent than TNF $\alpha$. So these data suggest that the enhanced production of IL18, ILl $\beta$, and TNF $\alpha$, characteristic of inflammation, stimulates $\mathrm{T}$ cells to produce RANKL, and then to promote osteoclast formation in RA synovitis (fig 7).

\section{ACKNOWLEDGEMENTS}

We thank Dr H Nakamura for his help in taking pictures and image analysis, and Dr K Konomi and Dr S Yamasaki for offering us RA samples. We deeply appreciate the help of the blood donors. 
This study was supported in part by a grant from the Japan Rheumatism Foundation and a Grant-in-Aid for General Scientific Research from the Ministry of Education, Science, and Culture of Japan and the Ministry of Health and Welfare of Japan.

\section{Authors' affiliations}

S-M Dai, K Nishioka, K Yudoh, Department of Bioregulation, Institute of Medical Science, St Marianna University School of Medicine, Kawasaki, Japan

S-M Dai, Department of Rheumatology and Immunology, Changhai Hospital, Second Military Medical University, Shanghai, China

\section{REFERENCES}

1 Kong YY, Yoshida H, Sarosi I, Tan HL, Timms E, Capparelli C, et al. OPGL is a key regulator of osteoclastogenesis, lymphocyte development and lymph-node organogenesis. Nature 1999:397:315-23.

2 Yasuda H, Shima N, Nakagawa N, Yamaguchi K, Kinosaki M, Mochizuki S, et al. Osteoclast differentiation factor is a ligand for osteoprotegerin/ osteoclastogenesis-inhibitory factor and is identical to TRANCE/RANKL. Proc Natl Acad Sci USA 1998;95:3597-602.

3 Lacey DL, Timms E, Tan HL, Kelley MJ, Dunstan CR, Burgess T, et al. Osteoprotegerin ligand is a cytokine that regulates osteoclast differentiation and activation. Cell 1998;93:165-76.

4 Wong BR, Rho J, Arron J, Robinson E, Orlinick J, Chao M, et al. TRANCE is a novel ligand of the tumor necrosis factor receptor family that activates $\mathrm{C}$-Jun $\mathrm{N}$-terminal kinase in T cells. J Biol Chem 1997;272:25190-4.

5 Simonet WS, Lacey DL, Dunstan CR, Kelley M, Chang MS, Luthy R, et al. Osteoprotegerin: a novel secreted protein involved in the regulation of bone density. Cell 1997;89:309-19.

6 Suda T, Takahashi N, Martin TJ. Modulation of osteoclast differentiation. Endocr Rev 1992;13:66-80.

7 Morony S, Capparelli C, Lee R, Shimamoto G, Boone T, Lacey DL, et al. A chimeric form of osteoprotegerin inhibits hypercalcemia and bone resorption induced by IL-1, TNF- $\alpha$, PTH, PTHrP and $1,25(\mathrm{OH})_{2} \mathrm{D}_{3}$. J Bone Miner Res $1999 ; 14: 1478-85$

8 Nakashima T, Kobayashi Y, Yamasaki S, Kawakami A, Eguchi K, Sasaki H et al. Protein expression and functional difference of membrane-bound and soluble receptor activator of NF-kappaB ligand: modulation of the expression by osteotropic factors and cytokines. Biochem Biophys Res Commun 2000;275:768-75.

9 Gravallese EM, Harada Y, Wang JT, Gorn AH, Thornhill TS, Goldring SR. Identification of cell types responsible for bone resorption in rheumatoid arthritis and juvenile rheumatoid arthritis. Am J Pathol 1998;152:943-51.

10 Gravallese EM, Manning C, Tsay A, Naito A, Pan C, Amento E, et al. Synovial tissue in rheumatoid arthritis is a source of osteoclast differentiation factor. Arthritis Rheum 2000;43:250-8.

11 Kotake S, Udagawa N, Hakoda M, Mogi M, Yano K, Tsuda E, et al. Activated human T cells directly induce osteoclastogenesis from human monocytes: possible role of $\mathrm{T}$ cells in bone destruction in rheumatoid arthritis patients. Arthritis Rheum 2001;44:1003-12.

12 Ukai T, Hara Y, Kato I. Effects of T cell adoptive transfer into nude mice on alveolar bone resorption induced by endotoxin. J Periodontal Res 1996;31:414-22

13 John V, Hock JM, Short LL, Glasebrook AL, Galvin RJ. A role for CD8+ T lymphocytes in osteoclast differentiation in vitro. Endocrinology 1996; 137:2457-63

14 Kong YY, Feige U, Sarosi I, Bolon B, Tafuri A, Morony S, et al. Activated T cells regulate bone loss and joint destruction in adjuvant arthritis through osteoprotegerin ligand. Nature 1999:402:304-9.

15 Horwood NJ, Kartsogiannis V, Quinn JM, Romas E, Martin TJ, Gillespie MT. Activated T lymphocytes support osteoclast formation in vitro. Biochem Biophys Res Commun 1999;265: 144-50.

16 Gracie JA, Forsey RJ, Chan WL, Gilmour A, Leung BP, Greer MR, et al. A proinflammatory role for IL-18 in rheumatoid arthritis. J Clin Invest 1999; 104:1393-401.

17 Leung BP, Mclnnes IB, Esfandiari E, Wei XQ, Liew FY. Combined effects of IL-12 and IL-18 on the induction of collagen-induced arthritis. J Immunol 2000; 164:6495-502.

18 Joosten LA, van De Loo FA, Lubberts E, Helsen MM, Netea MG, van Der Meer JW, et al. An IFN- $\gamma$-independent proinflammatory role of IL-18 in murine streptococcal cell wall arthritis. J Immunol 2000; 165:6553-8.
19 Wei XQ, Leung BP, Arthur HM, Mclnnes IB, Liew FY. Reduced incidence and severity of collagen-induced arthritis in mice lacking IL-18. J Immunol $2001 ; 166: 517-21$

20 Kawashima M, Miossec P. Heterogeneity of response of rheumatoid synovium cell subsets to interleukin-18 in relation to differential interleukin-18 receptor expression. Arthritis Rheum 2003;48:631-7.

21 Arnett FC, Edworthy SM, Bloch DA, McShane DJ, Fries JF, Cooper NS, et al. The American Rheumatism Association 1987 revised criteria for the classification of rheumatoid arthritis. Arthritis Rheum 1988;31:315-24.

22 Weitzmann MN, Cenci S, Rifas L, Brown C, Pacifici R. Interleukin-7 stimulates osteoclast formation by up-regulating the T-cell production of soluble osteoclastogenic cytokines. Blood 2000;96:1873-8.

23 Kobayashi K, Takahashi N, Jimi E, Udagawa N, Takami M, Kotake S, et al. Tumor necrosis factor alpha stimulates osteoclast differentiation by a mechanism independent of the ODF/RANKL-RANK interaction. J Exp Med 2000;191:275-86

24 Josien R, Wong BR, Li HL, Steinman RM, Choi Y. TRANCE, a TNF family member, is differentially expressed on T cell subsets and induces cytokine production in dendritic cells. J Immunol 1999;162:2562-8.

25 Tominaga K, Yoshimoto T, Torigoe K, Kurimoto M, Matsui K, Hada T, et al. IL12 synergizes with IL-18 or IL-1 beta for IFN-gamma production from human T cells. Int Immunol 2000;12:151-60.

26 Jones DH, Kong YY, Penninger JM. Role of RANKL and RANK in bone loss and arthritis. Ann Rheum Dis 2002;61(suppl II):ii32-9.

27 Kim N, Odgren PR, Kim DK, Marks SC Jr, Choi Y. Diverse roles of the tumor necrosis factor family member TRANCE in skeletal physiology revealed by TRANCE deficiency and partial rescue by a lymphocyteexpressed TRANCE transgene. Proc Natl Acad Sci USA 2000;97:10905-10.

28 Toraldo G, Roggia C, Qian WP, Pacifici R, Weitzmann MN. IL-7 induces bone loss in vivo by induction of receptor activator of nuclear factor kappa $B$ ligand and tumor necrosis factor alpha from T cells. Proc Natl Acad Sci USA 2003;100:125-30.

29 Weitzmann MN, Cenci S, Rifas L, Haug J, Dipersio J, Pacifici R. T cell activation induces human osteoclast formation via receptor activator of nuclear factor kappaB ligand-dependent and -independent mechanisms. J Bone Miner Res 2001;16:328-37.

30 Choi Y, Woo KM, Ko SH, Lee YJ, Park SJ, Kim HM, et al. Osteoclastogenesis is enhanced by activated $B$ cells but suppressed by activated $C D 8^{+} \mathrm{T}$ cells. Eur J Immunol 2001;31:2179-88.

31 Udagawa N, Horwood NJ, Elliott J, Mackay A, Owens J, Okamura H, et al. Interleukin-18 (interferon-gamma-inducing factor) is produced by osteoblasts and acts via granulocyte/macrophage colony-stimulating factor and not via interferon-gamma to inhibit osteoclast formation. J Exp Med 1997; 185:1005-12.

32 Horwood NJ, Udagawa N, Elliott J, Grail D, Okamura H, Kurimoto M et al. Interleukin 18 inhibits osteoclast formation via T cell production of granulocyte macrophage colony-stimulating factor. J Clin Invest 1998; 101:595-603.

33 Yoshimoto T, Takeda K, Tanaka T, Ohkusu K, Kashiwamura S, Okamura H et al. IL-12 up-regulates IL-18 receptor expression on T cells, Th1 cells, and B cells: synergism with IL-18 for IFN-gamma production. J Immunol 1998;161:3400-7.

34 Ogura T, Ueda H, Hosohara K, Tsuii R, Nagata Y, Kashiwamura S, et al. Interleukin-18 stimulates hematopoietic cytokine and growth factor formation and augments circulating granulocytes in mice. Blood 2001;98:2101-7

35 MacDonald BR, Mundy GR, Clark S, Wang EA, Kuehl TJ, Stanley ER, et al. Effects of human recombinant CSF-GM and highly purified CSF-1 on the formation of multinucleated cells with osteoclast characteristics in long-term bone marrow cultures. J Bone Miner Res 1986;1:227-33

36 Fujikawa Y, Sabokbar A, Neale SD, Itonaga I, Torisu T, Athanasou NA. The effect of macrophage-colony stimulating factor and other humoral factors (interleukin-1,-3,-6, and - 11, tumor necrosis factor-alpha, and granulocyte macrophage-colony stimulating factor) on human osteoclast formation from circulating cells. Bone 2001;28:261-7.

37 Liggett W Jr, Shevde N, Anklesaria P, Sohoni S, Greenberger J, Glowacki J. Effects of macrophage colony stimulating factor and granulocyte-macrophage colony stimulating factor on osteoclastic differentiation of hematopoietic progenitor cells. Stem Cells 1993;11:398-411.

38 Myint YY, Miyakawa K, Naito M, Shultz LD, Oike Y, Yamamura K, et al. Granulocyte/macrophage colony-stimulating factor and interleukin-3 correct osteopetrosis in mice with osteopetrosis mutation. Am J Pathol 1999; 154:553-66. 